\title{
PEMANFAATAN KAOLIN DALAM PEMBUATAN CAT TEMBOK MENGGUNAKAN "EMULSIFIER" Na- SILIKAT DAN PEREKAT \\ POLIVINIL ASETAT
}

\section{UTILIZATION IN MANUFACTURING KAOLIN WALL PAINT BY USING "EMULSIFIER" Na- SILICATE AND POLYVINYL ACETATE ADHESIVE}

\author{
A. Luther Ola \\ Balai Riset dan Standardisasi Industri Manado, \\ Jl. Diponegoro No. 21-23 Manado \\ e-mail: alexius.ola@gmail.com
}

Diterima : 13-04-2017

Direvisi : 16-05-2017

Disetujui : 29-05-2017

\begin{abstract}
ABSTRAK
Tujuan penelitian ini adalah untuk mempelajari pengaruh konsentrasi Emulifier dan perekat terhadap mutu cat tembok dengan bahan baku kaolin, menunjang pemanfaatan sebagai potensi sumber daya mineral secara maksimal serta diversifikasi produk dari kaolin. Penelitian ini disusun dengan Rancangan Acak Lengkap (RAL) yang disusun secara faktorial dan terdari dari 2 faktor yaitu: A. Konsentrasi emulsifier natrium silikat $(A 1=10 \% ; A 2=15 \% ; A 3=20 \%)$ dan $B$. Konsentrasi perekat polifinil asetat $(B 1=10 \% ; B 2=15 \%)$. Analisis mutu dilakukan secara kualitatif (sifat pengulasan, ketahanan terhadap alkali, ketahanan terhadap suhu) dan kuantitatif. Hasil penelitian menunjuan konsentrasi perekat berpengaruh terhadap padatan total cat tembok. Berat jenis cat tembok yang dibuat adalah 1:41 - 1:59, padatan total antara 50,37 - 54,82 \%, kehalusan -50 mikron, waktu mengering sekitar 30 - 50 menit. Parameter yang diuji secara kuantitatif dan kualitatif memenuhi persyaratan SNI:3564 - 2014 Cat tembok emulsi dan tahan terhadap alkali dan cuaca serta mudah diulaskan.
\end{abstract}

Kata kunci : kaolin, cat tembok, emulsifier, polivinil acetat

\begin{abstract}
The purpose of this research were to study the effect of the Emulsifier and adhesive concentration on the quality of wall paint by using kaolin raw materials, to support the maximum utilization of mineral resources potentials and to diversify other products of Kaolin. This study was prepared by Completely Randomized Design (CRD) arranged as factorial and consists of two factors, namely: $A$. The concentration of emulsifier sodium silicate $\left(A_{1}=10 \% ; A_{2}=15 \% ; A_{3}=20 \%\right)$ and $B$. The concentration of polyvinyl acetate adhesive $\left(B_{1}=10 \% ; B_{2}=15 \%\right)$. Quality analysis is conducted qualitatively (nature of the review, resistance to alkali, resistance to temperature). The results showed the concentration of total solids adhesives affects the paint. Specific gravity wall paint made is 1:41 to 1:59, total solids between 50,37 to 54,82\%, 5-micron fineness, time to dry for about 30 50 minutes. Parameters tested quantitatively and qualitatively meet the requirements of SNI 3564 2014 wall paint emulsion and resistant to alkali and weather as well as easy-to-apply around.
\end{abstract}

Keywords : kaolin, wall paint, emulsifier, polyvinyl acetate

\section{PENDAHULUAN}

$\mathrm{K}$

aolin adalah masa batu-batuan tanah lempung kualitas tinggi (high grade) yang mengandung besi dalam kadar yang rendah sekali dan biasanya berwarna putih atau mendekati putih.

Kaolin berasal dari feldspar dan 
terjadi karena proses-proses pelapukan pada permukaan bumi atau sebagai hasil pekerjaan hydrothermal yaitu larutan dan gas panas didalam bumi yang menguap, mengalir dan menerobos keatas.

Kaolin digunakan untuk berbagai keperluan terutama untuk bahan baku industri keramik, bata tahan api, pemberi warna putih dalam pengolahan kertas, industri tekstil, industri karet, industri cat, dan lain-lain. Kaolin adalah salah satu sumber daya alam dan merupakan bahan baku industri cat, yang belum dimanfaatkan sebagaimana mestinya di daerah Sulawesi Utara (Roeroe, 2000). Endapan kaolin di Sulawesi Utara tersebar di Kabupaten Minahasa (Toraget, Lahendong). Kabupaten Minahasa sudah pernah dieksplorasi dan diperkirakan cadangannya sebesar 20,000,000 $\mathrm{M}^{2}$ (Dinas Pertambangan Propinsi Sulawesi Utara, 2006). Dari data analisis mutu kaolin Minahasa yang pernah dilakukan ternyata kaolin daerah ini sangat cocok untuk industri cat tembok karena bersih dan halus. Walaupun potensi bahan baku cat tembok (kaolin) di Sulawesi Utara cukup besar, akan tetapi sampai saat ini belum ada industri cat tembok di daerah ini.

Cat tembok adalah cat emulsi yang terdiri dari 2 fase dimana salah satu fase adalah air yang merupakan media cair. Menurut SNI 3564 - 2014 cat tembok emulsi ialah campuran dari pigmen, bahan pengikat emulsi resin sintetik dan bahan tambahan lainnya yang digunakan terutama untuk tembok.

Pigmen adalah unsur penting dalam lapisan opak cat. Pigmen terdiri dari partikel-partikel halus yang tidak larut namun terdispersi pada bagian cair dari cat pigmen yang digunakan dalam pembuatan cat terdiri dari bermacam-macam warna dan jenis. Untuk pigmen putih dapat berupa $\mathrm{Pb}$ putih (white lead), titanium dioksida, seng osida, litophon, seng sulfit dan $\mathrm{Pb}$ sulfat Kaolin (China clay), talk, silika, asbes, gipsum, barit adalah ekstender atau inert dalam industri cat yang fungsinya untuk mengurangi biaya penggunaan pigmen dan untuk meningkatkan daya tutup dan ketahanan cuaca (Shreve, 1956).

Kaolin adalah pigmen inert dan mempunyai kecenderungan memberi kualitas terhadap cat dan memudahkan pengecatan. Karena kaolin bersifat inert sehingga pigmen ini tidak merubah atau merusakan bahan-bahan lain yang ditambahkan dalam pembuatan cat dan kaolin juga mencegah pengendapan dari bahan-bahan lain yang ditambahkan (Brushwell, 1973).

Seng oksida adalah salah satu pigmen putih yang penting dalam industri cat. Senyawa ini mempunyai opasitas yang tinggi serta daya tutup yang lebih baik daripada yang lain (Shreve, 1956). Penggunaan seng oksida dalam industri cat dapat dikombinasikan dengan pigmen putih yang lain seperti white lead, titanium oksida dan bahan-bahan pengisi (kaolin). Fungsi seng oksida dalam cat meningkatkan daya tahan cat dari pencucian air hujan, kerusakan cat dari gas udara, meningkatkan retensi warna, memberikan kontribusi terhadap daya tutup (Brushwell, 1973).

Dalam industri cat juga digunakan perekat dan salah satu jenis perekat yang sering digunakan adalah polivinil asetat yang disamping harganya relatif murah juga stabil terhadap cuaca, tahan air, asam, cepat kering dan mudah melekat serta mudah diolesan tanpa menimbulkan retak-retak (Golding, 1959).

Disamping itu juga digunakan natrium silikat yang berfungsi sebagai perekat dan emulsifier, dimana senyawa ini dalam cat juga tahan korosi, panas, air, rayap dan kerusakan oleh bakteri (Considine, 1974).

Persyaratan cat dibedakan terhadap jenis cat, untuk cat minyak mutu yang dipersyarakan berbeda dengan cat air begitu juga dalam macam pemakaian, cat tembok emulsi ditetapkan dengan SNI 3564 - 2014.

Tujuan penelitian ini adalah mempelajari pengaruh konsentrasi emulsifier dan perekat terhadap mutu cat 
tembok emulsi dengan bahan baku kaolin, menunjang pemanfaatan potensi sumber daya mineral secara maksimal serta diversifikasi produk dari kaolin.

\section{BAHAN DAN METODA}

Bahan dan Alat

Bahan yang digunakan dalam penelitian ini meliputi kaolin, lithophon, seng oksida, natrium silikat, polivinil asetat, natrium hidroksida.

Alat bantu dan peralatan yang digunakan antara lain loyang dan ember plastik, serbet, masker, sarung tangan, timbangan kasar, gergaji, kuas, pengaduk dan peralatan laboratorium lainnya.

\section{Metoda}

Penelitian ini menggunakan percobaan faktorial dengan metoda Rancang Acak Lengkap (RAL) dengan perlakuan sebagai berikut:

a. Konsentrasi emulsifier (pengemulsi)

$A_{1}=10 \%$

$A_{2}=15 \%$

$A_{3}=20 \%$

b. Konsentrasi perekat

$\mathrm{B}_{1}=10 \%$

$B_{2}=15 \%$

Penelitian dilakukan 2 kali (ulangan).

\section{Tahapan Pekerjaan \\ Persiapan bahan baku}

Kaolin dalam bentuk bongkahan direndam air dalam loyang plastic selama kurang lebih ( $1 \times 24$ jam), diaduk hingga bongkahan kaolin hancur, lalu disaring dengan ayakan 200 mesh sambil dialiri air sedikit demi sedikit, dibiarkan beberapa saat (1 Jam) hingga terjadi pemisahan antara kaolin dan air. Air pada bagian atas dibuang, endapan kaolin dikeringkan pada sinar matahari dan selanjutnya disimpan sebagai bahan baku cat.

\section{Pembuatan Cat Tembok}

- Ditimbang masing-masing bahan yang terdiri dari: kaolin $360 \mathrm{~g}$, lithophon 80 $\mathrm{g}$, seng oksida $60 \mathrm{~g}$, natrium silikat (konsentrasi sesuai perlakuan yaitu: $10 \%, 15 \%$ dan 20\%), dalam air $250 \mathrm{~g}$, dan polivinil asetat (konsentrasi sesuai perlakuan terdiri: $10 \%$ dan $15 \%$ ) dalam air $150 \mathrm{~g}$, sehingga jumlah seluruh campuran $1000 \mathrm{~g}$.

- Aduk campuran di atas hingga homogen (dengan alat pencampur mekanik selama 30 menit) dan dihasilkan cat tembok emulsi.

- Simpan cat tembok emulsi dalam kaleng atau ember plastik tertutup rapat dan siap untuk dianalisis mutu.

\section{Pengamatan}

Parameter yang diamati meliputi:

a. Kuantitatif: berat jenis (ASTM Part 27,1980), kehalusan (SNI 3564 - 2014), waktu mengering (ASTM Part 27,1980), padatan total (ASTM Part 27,1980).

b. Kualitatif: (SNI 3564 - 2014) sifat pengulasan, ketahanan terhadap alkali, ketahanan terhadap cuaca.

\section{HASIL DAN PEMBAHASAN}

Hasil pengujian mutu cat tembok yang dibuat dari kaolin dapat dilihat pada Tabel 1.

\section{A. Analisis Kuantitatif}

a. Berat Jenis

Dari hasil analisis berat jenis cat tembok emulsi terlihat bahwa perlakuan penambahan $20 \%$ emulsifier natrium silikat dan $15 \%$ perekat polivinil asetat memberikan nilai berat jenis tertinggi yaitu 1,59 sedangkan cat tembok yang dibuat dengan penambahan $15 \%$ emulsifier dan $10 \%$ polivinil asetat mempunyai berat jenis terendah yakni 1,41 . Hasil analisis statistik menunjukan bahwa perlakuan konsentrasi emulsifier natrium silikat dan perekat polivinil asetat dan interaksi keduanya tidak memberikan pengaruh terhadap berat jenis. Salah satu indikator untuk mengetahui mutu cat tembok ditentukan oleh nilai berat jenis. Karena semakin tinggi berat jenis, maka mutu cat akan semakin baik, dimana hal ini ada hubungannya dengan pengenceran. Jika berat jenis cat tembok tinggi, maka air yang digunakan untuk pengenceran dalam pemakaian pengecetan semakin banyak dengan demikian akan menghemat 
pemakaian/pembelian dalam jumlah besar.

Berat jenis cat ditentukan oleh jenis bahan yang digunaan dalam produksi cat. Menurut SNI 3564 - 2014 berat jenis cat tembok emulsi dipersyaratkan minimun 1,2 .

Hasil analisis cat tembok emulsi yang dibuat dengan bahan baku kaolin menunjukan nilai berat jenis rata-rata dengan kisaran 1,42-1,59 memenuhi persyaratan SNI. Tingginya nilai berat jenis cat tembok hasil penelitian disebaban oleh antara lain pengaruh penggunaan bahan baku kaolin, karena kaolin mempunyai berat jenis yang cukup tinggi yakni 2,6-2,63, (Maryam 2005). sehingga meningkatkan nilai berat jenis cat yang di produksi.

Tabel 1 : Hasil Analisis Kuantitatif Cat Tembok Emulsi

\begin{tabular}{ccccc}
\hline $\begin{array}{c}\text { ode } \\
\text { Contoh }\end{array}$ & $\begin{array}{c}\text { Berat } \\
\text { Jenis }\end{array}$ & $\begin{array}{c}\text { Total Padatan } \\
(\%)\end{array}$ & $\begin{array}{c}\text { Kehalusan } \\
\text { (Mikron) }\end{array}$ & $\begin{array}{c}\text { Waktu Mengering } \\
\text { (Menit) }\end{array}$ \\
\hline $\mathrm{A}_{1} \mathrm{~B}_{1}$ & 1,45 & 50,38 & $=50$ & 37 \\
$\mathrm{~A}_{1} \mathrm{~B}_{2}$ & 1,47 & 53,25 & $=50$ & 45 \\
$\mathrm{~A}_{2} \mathrm{~B}_{1}$ & 1,42 & 50,76 & $=50$ & 33 \\
$\mathrm{~A}_{2} \mathrm{~B}_{2}$ & 1,44 & 51,04 & $=50$ & 44 \\
$\mathrm{~A}_{3} \mathrm{~B}_{1}$ & 1,56 & 52,01 & $=50$ & 42 \\
$\mathrm{~A}_{3} \mathrm{~B}_{2}$ & 1,59 & 53,64 & $=50$ & 46 \\
\hline
\end{tabular}

b. Total Padatan

Hasil analisis statistik menunjukan bahwa perlakuan konsentrasi perekat polivinil asetat memberikan pengaruh nyata terhadap kandungan padatan total, sedangkan perlakuan konsentrasi emulsifier natrium silikat dan interaksi kedua perlakuan tidak memberikan pengaruh teradap padatan total. Uji BNT untuk perlakuan konsentrasi perekat menunjukan konsentrasi perekat $10 \%$ berbeda nyata terhadap konsentrasi perekat $15 \%$. Data diatas menunjukan semakin tinggi konsentrasi polivinil asetat yang ditambahkan maka kandungan padatan total makin meningkat. Hal ini dapat terjadi karena beberapa faktor yaitu antara lain, faktor sifat fisik polivinil asetat yang digunakan mempunyai sifat padat dan pada pemanasan diatas $105^{\circ} \mathrm{C}$ (analisis total padatan) belum mengalami penguraian (hilang/menguap) dan hanya membentuk lapisan film (mencair). Menurut Golding,B. (1959) polivinil asetat tahan terhadap pemanasan tinggi. Kadar padatan total dari cat tembok yang dianalisis berkisar antara 50,37\% 54,82\%, SNI 3564 - 2014 mensyaratkan minimum $40 \%$.

\section{c. Kehalusan}

Berdasarkan pengujian ternyata cat tembok yang dibuat dapat melewati ayakan yang mempunyai ukuran 50 mikrons. Data ini menunjukan bahwa bahan baku maupun bahan penolong yang digunakan dalam pembuatan cat tembok ini mempunyai kehalusan maksimum 50 mikron dan senyawa perekat telah bercampur sempurna. Persyaratan mutu cat tembok SNI 3564 - 2014 untuk parameter kehalusan adalah maksimum 50 mikron.

\section{d. Waktu Mengering \\ Hasil pengujian pada suhu ruang} adalah antara 30-50 menit. Adanya 
perbedaan waktu mengering antara perlakuan yang satu dengan yang lain dapat terjadi karena pengaruh cara pengecatan dimana ada bagian-bagian dari benda uji (eternit $30 \times 10 \times 0 *, 3 \mathrm{~cm}$ ) mengalami penebalan cat pada waktu dioleskan dan ada bagian yang tipis dengan sendirinya pada bagian yang tebal lapisan catnya akan lama kering dibandingkan pada bagian yang tipis.

Faktor pengenceran dengan air turut ikut juga mempengaruhi waktu pengering karena semakin banyak air yang digunaan untukmengencerkan cat tembok, akan semakin lama mengering. Polivinil asetat merupakan suatu resin sintetik yang bersifat termoplastik, jika sudah mencair dan dioleskan pada permukaan yang datar akan cepat mengering. Menurut SNI 3564
- 2014, waktu mengering cat tembok emulsi maksimum 1 jam setelah pengecetan. Dengan demikian cat tembok emulsi hasil penelitian untuk parameter ini masih memenuhi syarat berdasarkan standar yang ada. Hal ini dapat disebabkan adanya penggunaan perekat polivinil asetat yang dapat mempercepat proses pengeringan cat tembok. Penggunaan polivinil acetat ditunjang dengan pendapat Arthur and Rose, $E_{\text {, }}$. 1961, yang menyatakan bahwa polivinil asetat banyak digunakan dalam cat air karena bersifat cepat kering.

\section{B. Analisis Kualitatif}

Selain persyaratan kuantitatif, maka cat tembok emulsi mempunyai persyaratan kualitatif (SNI 3564 - 2014). Adapun hasil pengujian kualitatif dapat dilihat pada Tabel 2.

Tabel 2. Hasil Analisis Kualitatif Cat Tembok Emulsi

\begin{tabular}{|c|c|c|c|c|}
\hline $\begin{array}{l}\text { Kode } \\
\text { Contoh }\end{array}$ & Ulangan & Sifat Pengulasan & $\begin{array}{c}\text { Ketahanan Terhadap } \\
\text { Alkali } \\
\end{array}$ & $\begin{array}{c}\text { Ketahanan Terhadap } \\
\text { Cuaca } \\
\end{array}$ \\
\hline$A_{1} B_{1}$ & 1 & $\begin{array}{l}\text { Mudah diulaskan, halus, } \\
\text { rata, } \\
\text { tidak berkerut }\end{array}$ & $\begin{array}{l}\text { Tanpa pengapuran, tidak } \\
\text { berkerut, } \\
\text { tidak terkelupas, tidak berubah } \\
\text { warna }\end{array}$ & $\begin{array}{l}\text { Tanpa pengapuran, } \\
\text { tidak berubah } \\
\text { warna, tidak } \\
\text { terkelupas }\end{array}$ \\
\hline$A_{1} B_{2}$ & 1 & $\begin{array}{l}\text { Mudah diulaskan, halus, } \\
\text { rata, } \\
\text { tidak berkerut }\end{array}$ & $\begin{array}{l}\text { Tanpa pengapuran, tidak } \\
\text { berkerut, } \\
\text { tidak terkelupas, tidak berubah } \\
\text { warna }\end{array}$ & $\begin{array}{l}\text { Tanpa pengapuran, } \\
\text { tidak berubah } \\
\text { warna, tidak } \\
\text { terkelupas }\end{array}$ \\
\hline $\mathrm{A}_{2} \mathrm{~B}_{1}$ & 1 & $\begin{array}{c}\text { Mudah diulaskan, halus, } \\
\text { rata, } \\
\text { tidak berkerut } \\
\end{array}$ & $\begin{array}{c}\text { Tanpa pengapuran, tidak } \\
\text { berkerut, } \\
\text { tidak terkelupas, tidak berubah } \\
\text { warna } \\
\end{array}$ & $\begin{array}{l}\text { Tanpa pengapuran, } \\
\text { tidak berubah } \\
\text { warna, tidak } \\
\text { terkelupas } \\
\end{array}$ \\
\hline$A_{2} B_{2}$ & 1 & $\begin{array}{c}\text { Mudah diulaskan, halus, } \\
\text { rata, } \\
\text { tidak berkerut }\end{array}$ & $\begin{array}{c}\text { Tanpa pengapuran, tidak } \\
\text { berkerut, } \\
\text { tidak terkelupas, tidak berubah } \\
\text { warna }\end{array}$ & $\begin{array}{l}\text { Tanpa pengapuran, } \\
\text { tidak berubah } \\
\text { warna, tidak } \\
\text { terkelupas }\end{array}$ \\
\hline$A_{2} B_{1}$ & 1 & $\begin{array}{c}\text { Mudah diulaskan, halus, } \\
\text { rata, } \\
\text { tidak berkerut }\end{array}$ & $\begin{array}{c}\text { Tanpa pengapuran, tidak } \\
\text { berkerut, } \\
\text { tidak terkelupas, tidak berubah } \\
\text { warna } \\
\end{array}$ & $\begin{array}{l}\text { Tanpa pengapuran, } \\
\text { tidak berubah } \\
\text { warna, tidak } \\
\text { terkelupas }\end{array}$ \\
\hline$A_{1} B_{2}$ & 1 & $\begin{array}{c}\text { Mudah diulaskan, halus, } \\
\text { rata, } \\
\text { tidak berkerut } \\
\end{array}$ & $\begin{array}{c}\text { Tanpa pengapuran, tidak } \\
\text { berkerut, } \\
\text { tidak terkelupas, tidak berubah } \\
\text { warna }\end{array}$ & $\begin{array}{l}\text { Tanpa pengapuran, } \\
\text { tidak berubah } \\
\text { warna, tidak } \\
\text { terkelupas } \\
\end{array}$ \\
\hline
\end{tabular}




\section{a. Sifat Pengulasan}

Hasil pengujian sifat pengulasan ternyata cat tembok yang dibuat dari bahan baku kaolin setelah dicobakan pada benda uji (enternit $30 \times 10 \times 0,3 \mathrm{~cm}$ ) dapat mudah diulaskan dengan kuas dan lapisan kering cat adalah halus, rata, tidak berkerut dan tidak turun. Untuk parameter ini cat tembok hasil penelitian memenuhi syarat SNI 3564 - 2014.

Sifat pengulasan akan memberikan hasil baik apabila bahan-bahan penyatuan cat adalah baik dan dapat bergabung dengan homogen antara bahan yang satu dengan lainnya.

Bahan-bahan yang digunakan dalam pembuatan cat tembok emulsi ini ternyata setelah dicampurkan dan diproses menjadi cat memberikan hasil optimal (hasil yang baik dari sifat pengulasan). Hal ini menunjukan bahwa bahan-bahan tersebut dapat saling mengisi satu dengan yang lainnya dan masing-masing bahan memberikan kontribusi terhadap kualitas cat tembok. Hal ini ditunjang dengan pendapat dari Bruswell (1973) yang menyatakan bahwa kaolin bersifat inert sehingga pigmen ini tidak merubah atau merusakan dan mencegah pengendapat bahan-bahan lain yang ditambahkan dalam pembuatan cat. Sehingga oksida setelah dicampurkan dengan kaolin akan memberikan hasil baik dalam produk cat tembok emulsi.

Bruswell (1973) juga menyatakan bahwa seng oksida dalam industri cat dapat dikombinasikan dengan bahan pengisi (kaolin) sedangkan penambahan polivinil asetat mempermudah pengulasan cat tembok.

Golding, (1959) menyatakan bahwa karena berat jenis polivinil asetat rendah sehingga jika dicampurkan sebagai perekat dalam cat akan mudah dioleskan tanpa menimbulkan retakretak/pecah.

\section{b. Ketahanan Terhadap Alkali}

Produk cat tembok hasil penelitian setelah dilakukan pengujian ketahanan terhadap alkali memperlihatkan tidak ada pengapuran, pengkerutan, pengelupasan dan setelah dikeringkan selama $1 / 2$ jam tidak ada perubahan warna (Tabel 2). Hal ini menunjukan bahan-bahan yang digunakan dalam pembuatan cat setelah dicampurkan dan diproses menjadi cat tembok bersifat tahan terhadap alkali. Salah satu faktor yang menunjang sehingga produk cat tahan terhadap alkali adalah bahan-bahan tersebut sifat dasarnya tahan terhadap alkali bersifat inert seperti kaolin.

Menurut Brushwell (1973) kaolin dikelompokan dalam pigmen putih dan merupakan pigmen inert. Juga penggunaan natrium silikat mempertinggi ketahanan cat terhadap cuaca.

\section{c. Ketahanan Terhadap Cuaca}

Cat tembok yang diulaskan pada benda uji setelah dilakukan pengujian ketahanan terhadap cuaca baik siang dan malam $\left(20-50^{\circ} \mathrm{C}\right)$ pada pemakaian 1 (satu) bulan memperlihatkan tidak ada pengapuran, perubahan warna dan pengelupasan. Faktor ketahanan terhadap cuaca merupakan parameter yang dapat dijadikan petunjuk baik buruknya kualitas cat tembok emulsi. Karena pemakaian cat tembok adalah ruangan atau interior maupun diluar ruangan atau eksterior. Cat tembok hasil penelitian ternyata sampai pada pemakaian satu bulan untuk parameter ketahanan terhadap cuaca masih memenuhi persyaratan SNI 35642014. Hal ini menunjukkan bahwa komposisi bahan-bahan yang digunakan dalam proses pembuatan cat tembok emulsi ini mempunyai ketahanan yang baik terhadap cuaca. Masing-masing bahan penyusun cat tembok emulsi saling melengkapi meningkatkan mutu produk khususnya ketahanan terhadap cuaca.

$$
\text { Menurut Brushwell }
$$

lithophon dalam cat emulsi berfungsi meningkatkan penampilan dan melindungi cat dari pengelupasan. Sedangkan seng oksida berfungsi meningkatkan daya tahan pencucian oleh air hujan dan kerusakan oleh gas-gas diudara. Begitu juga polivinil asetat dalam cat memberikan kombinasi terhadap ketahanan cuaca karena sifatnya yang 
termoplastik dan transparan. Arthur and Rose, (1961) menyatakan bahwa polivinil asetat banyak digunaan dalam cat air karena stabil terhadap cuaca, tahan terhadap air dan asam.

\section{KESIMPULAN}

Perlakuan konsentrasi emulsifier tidak berpengaruh terhadap berat jenis dan padatan total cat tembok emulsi dari bahan baku kaolin, sedangkan konsentrasi perekat memberikan pengaruh terhadap padatan total cat tembok yang dihasilkan.

Kombinasi perlakuan yang dihasilkan mutu cat tembok emulsi terbaik diperoleh dari perlakuan konsentrasi emulsifier $20 \%$ dan perekat $15 \%$ dengan karakteristik sebagai berikut: Berat Jenis 1,59, Padatan Total 54,82 dan tahan terhadap alkali dan cuaca serta mudah diulaskan.

\section{DAFTAR PUSTAKA}

Anonim, 1980. Annual Book of ASTM Standards, Part 27. American Society for Testing and Materials, Philadelphia.

Anonim, 1980. Annual Book of ASTM Standards, Part 28. American Society for Testing and Materials, Philadelphia.

Anonim, 1980. Annual Book of ASTM Standards, Part 29. American Society for Testing and Materials, Philadelphia.

Anonim, 2006. Potensi dan Prospek Pengembangan Bahan Galian C di SULUT. Dinas Pertambangan Propinsi Dati I, Sulawesi Utara.

Arthur and Rose, E., 1961. The Condensed Chemical Dictinary, Sixth edition. Reinhold Publishing Corporation, New York.

Brushwell, W., 1973. Painting and Decorating Encyclopedia. The Goodfather Willcox Co. Inc. South Holland.

Considine. D.M., 1974. Chemical and Process Technology Encyclopedia. Mc. Graw Hill Book Company, New York.
Golding, B., 1959. Polymers and Resins. D. Van Nostrand Company, Inc. Pricetone. New Jersey.

Maryam dkk 2005 Pengembangan Pendayagunaan Kaolin sebagai Bahan Baku Keramik. Balai Riset dan Standardisasi Industri Manado.

Roeroe, HJ. 2000. Penelitian Pemanfaatan Tanah Liat, Kaolin, Felspar dan Kuarsa untuk Keramaik Non Gerabah, Balai penelitian dan Pengembangan Industri Manado, Manado.

Shreve, R.N., 1956. Chemical Process Industries, Second Edition, Mc. Graw-Hill Book Company, Inc., London.

BSN, 2014. SNI 3564-2014-Cat Tembok Emulsi, Badan Standardisasi Nasional, Jakarta, Indonesia. 